\title{
Early Jurassic accretion of high- pressure granulites in the Amdo complex, Bangong-Nujiang suture zone, central Tibet
}

\author{
Z. TIAN ${ }^{1,2}$, Z. ZHANG ${ }^{1}$, X. DONG ${ }^{1}$ \\ AND P. M. PICCOLI ${ }^{2}$
}

${ }^{1}$ Key Laboratory of Deep-Earth Dynamics of Ministry of Natural Resources, Institute of Geology, Chinese Academy of Geological Sciences, Beijing 100037, China (zuolin.tian@gmail.com)

${ }^{2}$ Laboratory for Crustal Petrology, Department of Geology, University of Maryland, College Park, Maryland 20742, U.S.A.

The timing of ocean closure and thermal evolution of the crust in the Bangong-Nujiang suture zone (BNSZ) in central Tibet, which separates the Qiangtang terrane to the north and the Lhasa terrane to the south, are controversial. In this circumstance, we combine petrology, zircon $\mathrm{U}-\mathrm{Pb}$ geochronology and phase equilibrium modeling to determine the $P-T-t$ paths of high-pressure granulites from the Amdo complex in the central part of BNSZ. Type-I orthopyroxenebearing granulites, which occur in the north as lenses in orthogneisses with a prominent migmatitic texture, record nearly isothermal decompression $P-T$ paths from a HP granulite facies $P-T$ field at $15-17 \mathrm{kbar}$ and $750-780{ }^{\circ} \mathrm{C}$ to a $P-T$ field at $\sim 4$ kbar and $800-820^{\circ} \mathrm{C}$ at $c$. $182-181 \mathrm{Ma}$. By contrast, in the south orthogneisses without any migmatitic structure host lenses of type-II orthopyroxene-absent granulites. Type-II granulites record "hairpin" clockwise $P-T$ path characterized by compression and heating from $\sim 5 \mathrm{kbar}$ at $\sim 450{ }^{\circ} \mathrm{C}$ to peak granulite facies $P-T$ conditions of $11-13.5$ kbar at $620-760{ }^{\circ} \mathrm{C}$, followed by an isothermal decompression to the $P$ of $\sim 8-10$ kbar at $c$. 182 Ma and near isobaric cooling. The spatial relations (type-I granulites in the north) and higher peak $P-T$ conditions of the type-I granulites, suggest the Amdo complex was a product of northward subduction beneath the Qiangtang terrane. Based on the protolith age for type-II granulites $(c .184 \mathrm{Ma})$ and one young gabbro from the Amdo ophiolite (c. $184 \mathrm{Ma}$ ) that represents the intra-oceanic arc-backarc basin complex between the Qiangtang terrane to the north and the Amdo complex, we propose that both types of granulites experienced fast burial to $\sim 13-17$ kbar before exhumation to $\sim 9$ kbar within $2 \mathrm{Ma}$. 